\title{
National Weatherization Assistance Program Evaluation: Assessment of Refrigerator Energy Use
}

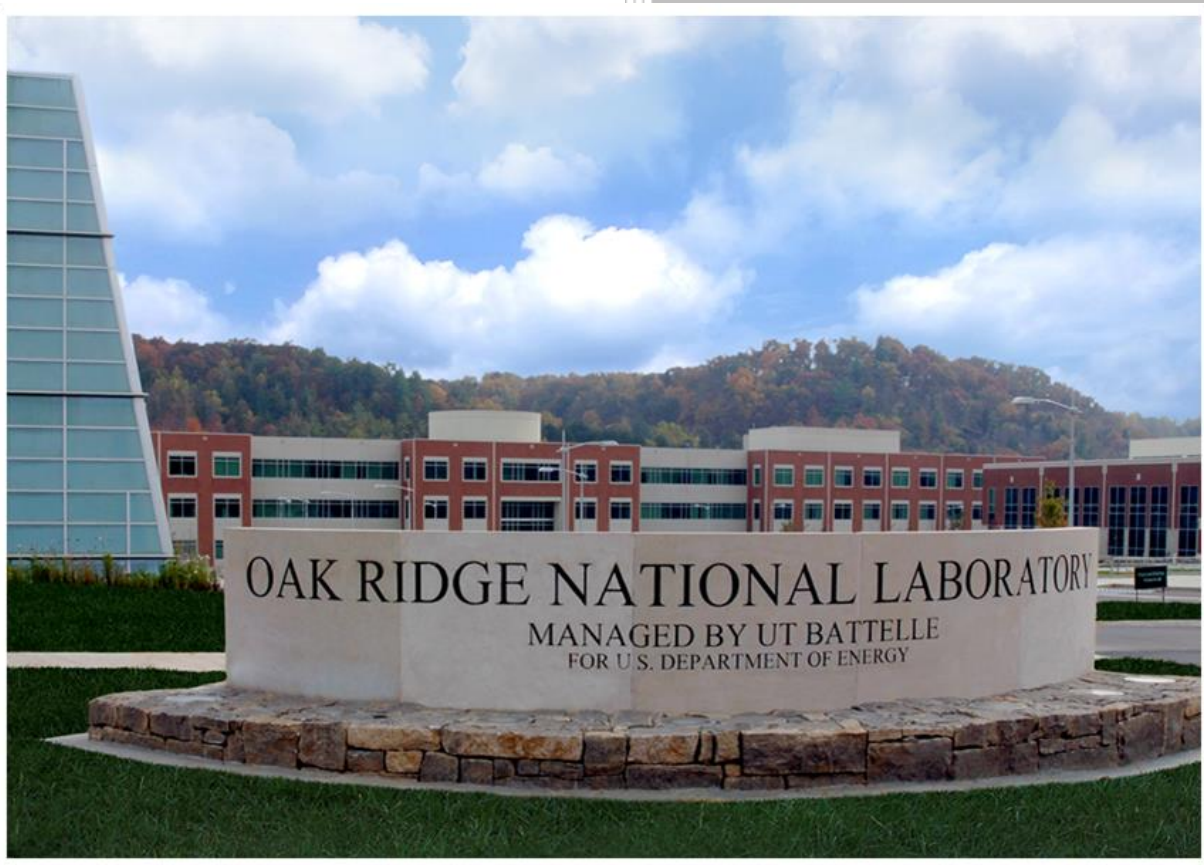

Bruce Tonn

Richard Goeltz

March 2015 


\title{
DOCUMENT AVAILABILITY
}

Reports produced after January 1, 1996, are generally available free via US Department of Energy (DOE) SciTech Connect.

Website http://www.osti.gov/scitech/

Reports produced before January 1, 1996, may be purchased by members of the public from the following source:

\author{
National Technical Information Service \\ 5285 Port Royal Road \\ Springfield, VA 22161 \\ Telephone 703-605-6000 (1-800-553-6847) \\ TDD 703-487-4639 \\ Fax 703-605-6900 \\ E-mail info@ntis.gov \\ Website http://www.ntis.gov/help/ordermethods.aspx
}

Reports are available to DOE employees, DOE contractors, Energy Technology Data Exchange representatives, and International Nuclear Information System representatives from the following source:

Office of Scientific and Technical Information

PO Box 62

Oak Ridge, TN 37831

Telephone 865-576-8401

Fax 865-576-5728

E-mail reports@osti.gov

Website http://www.osti.gov/contact.html

This report was prepared as an account of work sponsored by an agency of the United States Government. Neither the United States Government nor any agency thereof, nor any of their employees, makes any warranty, express or implied, or assumes any legal liability or responsibility for the accuracy, completeness, or usefulness of any information, apparatus, product, or process disclosed, or represents that its use would not infringe privately owned rights. Reference herein to any specific commercial product, process, or service by trade name, trademark, manufacturer, or otherwise, does not necessarily constitute or imply its endorsement, recommendation, or favoring by the United States Government or any agency thereof. The views and opinions of authors expressed herein do not necessarily state or reflect those of the United States Government or any agency thereof. 
Environmental Sciences Division

\title{
National Weatherization Assistance Program Evaluation: Assessment of Refrigerator Energy Use
}

\author{
Bruce Tonn, ORNL \\ Richard Goeltz, ORNL
}

March 2015

Prepared by

OAK RIDGE NATIONAL LABORATORY

Oak Ridge, TN 37831-6283

managed by

UT-BATTELLE, LLC

for the

US DEPARTMENT OF ENERGY

under contract DE-AC05-00OR22725 



\section{CONTENTS}

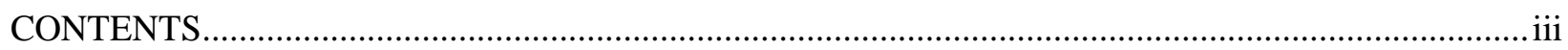

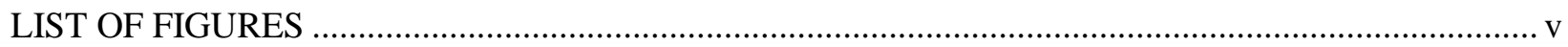

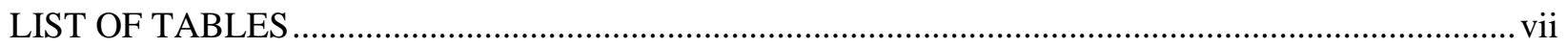

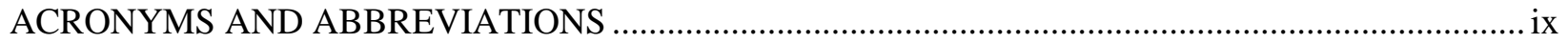

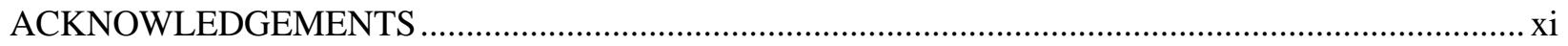

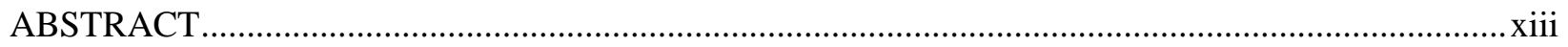

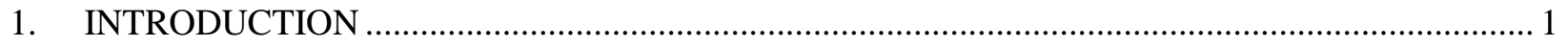

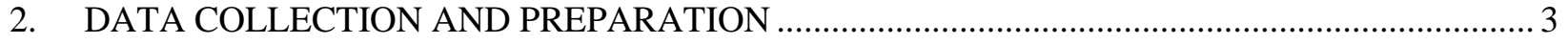

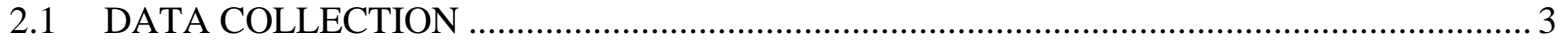

2.2 PREPARATION OF THE REFRIGERATOR TEMPERATURE DATA FOR

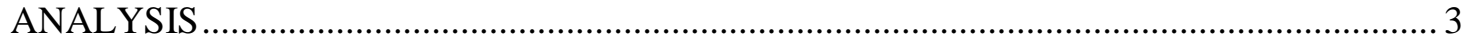

2.3 PREPARATION OF THE REFRIGERATOR POWER DATA FOR ANALYSIS ................... 4

3. REFRIGERATOR CHARACTERIZATION AND PERFORMANCE ......................................... 7

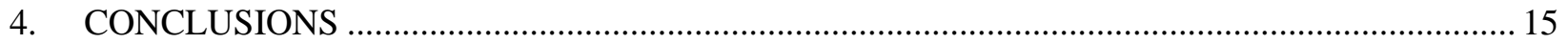

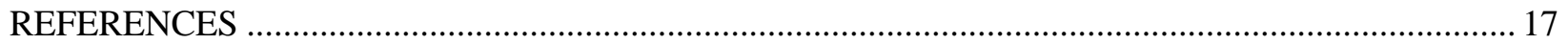





\section{LIST OF FIGURES}

Figure

Figure 1.1 Sampled Geographic Areas ....................................................................................... 1

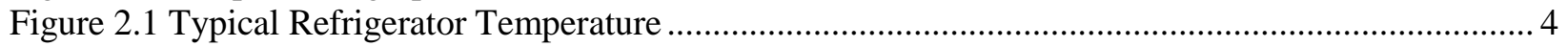

Figure 2.2 Example of Refrigerator Power (watts) Over Time (in minutes) …....................................... 5

Figure 3.1 Year Primary Refrigerator Was Manufactured (in \%) .................................................... 9

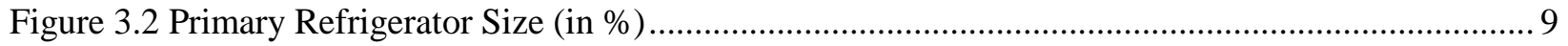

Figure 3.4 Example Where the Refrigerator Temperature was Always Above $42{ }^{\circ} \mathrm{F}$.............................. 10

Figure 3.5 Annual Refrigerator Electricity Consumption (kWh/year) ................................................. 11

Figure 3.6 Average Household Refrigerator Energy Use, Volume, and Price Over Time ........................ 12

Figure 3.7 Annualized Refrigerator Energy Consumption by Healthy Refrigerator Score ....................... 13 



\section{LIST OF TABLES}

Table

Page

Table 2.1 Number of Refrigerators with Power Data ....................................................................... 3

Table 2.2 Number of Refrigerators with Minimum and Maximum Recorded ......................................... 4

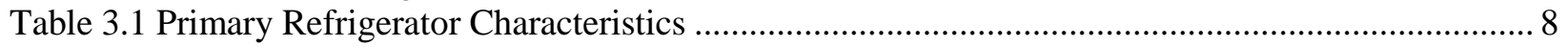

Table 3.2 Average Refrigerator Temperature Measurements ........................................................... 9

Table 3.3 Characteristics of Refrigerators That Do and Do Not Maintain Temperature Less than

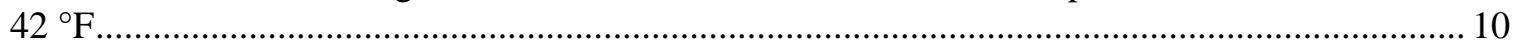

Table 3.4 Refrigerator Regression Model: Dependent Variable Annual Energy Consumption ................. 12 



\section{ACRONYMS AND ABBREVIATIONS}

$\begin{array}{ll}\text { CSV } & \text { Comma Separated Value } \\ \text { DOE } & \text { U.S. Department of Energy } \\ \text { EPA } & \text { U.S. Environmental Protection Agency } \\ \text { FDA } & \text { U.S. Food and Drug Administration } \\ \text { HVAC } & \text { Heating, Ventilation and Air Conditioning } \\ \text { IAQ } & \text { Indoor Air Quality } \\ \text { kWh } & \text { Kilowatt Hour } \\ \text { ORNL } & \text { Oak Ridge National Laboratory } \\ \text { OWIP } & \text { Office of Weatherization and Intergovernmental Program } \\ \text { USDA } & \text { U.S. Department of Agriculture } \\ \text { WAP } & \text { Weatherization Assistance Program }\end{array}$





\section{ACKNOWLEDGEMENTS}

The work presented in this report was funded by the U.S. Department of Energy's (DOE) Office of Weatherization and Intergovernmental Programs (OWIP). We wish to acknowledge the assistance provided by the Energy Center of Wisconsin and APPRISE, Inc. in collecting refrigerator energy-use and other data utilized in this research. We also wish to thank Mark Ternes for his technical assistance. 



\begin{abstract}
This report assess the characteristics and performance of refrigerators found in a sample of homes eligible to receive services from the U.S. Department of Energy's Weatherization Assistance Program. The refrigerators studied for this research were located in homes that participated in a larger study of the impacts of weatherization on indoor air quality. The study primarily focuses on a set of 382 primary refrigerators and data collected about their operation pre-weatherization. The typical refrigerator found in the study homes was manufactured after the year 2000, has a capacity of 18 cubic feet, and has a top freezer. Only $27 \%$ of the primary refrigerators are located in kitchens and $34 \%$ are not located in conditioned spaces. Only $23 \%$ of the refrigerators had an energy-saver switch and of these, only 55\% of the switches were observed to be in the on position. The preponderance of the refrigerators' inside temperatures was below the recommended $42{ }^{\circ} \mathrm{F}$, though this threshold was exceeded the entire metering time for three refrigerators. The average annualized electricity consumption for a refrigerator in the sample was $756 \mathrm{kWh} /$ year. The median was $651 \mathrm{kWh} /$ year. The variation in consumption has many possible explanations, including: refrigerator capacity, age, indoor temperatures, location in unconditioned spaces, number of individuals in the household (e.g., influencing the number of door openings), number of operating options, and simple disrepair. It should be noted that the average electricity consumption of this set of refrigerators is possibly an underestimate given that the data were collected during the winter, the majority of the study houses are located in cold to very cold climates, and a large percentage of the refrigerators are located in unconditioned spaces. As expected, the age and capacity of refrigerators are positively and statistically related to annual energy use. Refrigerators that operate at unhealthy temperatures for much of the time use less energy on average.
\end{abstract}





\section{INTRODUCTION}

The U.S. Department of Energy (DOE) administers the Weatherization Assistance Program (WAP). The main objectives of this study are to assess the characteristics, performance and energy-use of refrigerators found in a sample of homes eligible for WAP services. Briefly, WAP provides grants, guidance, and other support to Grantees: weatherization programs administered by each of the 50 states, the District of Columbia, territories and several Native American tribes. The Grantees, in turn, oversee a network of $900+$ local weatherization agencies (Subgrantees): community action agencies, nonprofit organizations, and local government agencies that are eligible to receive weatherization funding from DOE. These weatherization agencies qualify eligible households, assess their homes' energy efficiency opportunities, install energy-saving measures, and inspect the work. The work performed includes air sealing, insulation upgrades, furnace replacements, and other dwelling-specific measures found to be cost-effective, as well as home improvements needed to ensure the health and safety of household occupants. The work is done at no cost to the eligible participants.

This study is one component of the national evaluation of WAP conducted by Oak Ridge National Laboratory (ORNL) on behalf of DOE. The main purpose of the overall evaluation - and the collection of reports stemming from this work 1 - are to provide a comprehensive review of Program performance to enable DOE to guide the future direction of the program, as well as to provide information to potential funders in order to support leveraging activities. More specifically, this study of refrigerators is part of a larger study of indoor air quality (IAQ). The IAQ study involved testing and monitoring in 514 singlefamily homes (including mobile homes) located in 35 states and served by 88 local weatherization agencies. ${ }^{2}$ Figure 1.1 indicates the geographic areas included in the study. Approximately a third of the homes (189 homes) were randomly assigned to a control group. The primary thrust of the IAQ study was to assess impacts of the typical weatherization job on these five indoor air quality parameters: carbon monoxide, radon, formaldehyde, humidity, and moisture. As a minor, secondary task, the IAQ study gathered direct field data on refrigerators, including temperature and power consumption. Thus, this report is a follow up to the original IAQ report with analysis of the IAQ refrigerator data focusing on refrigerator characteristics, performance and ultimately, energy use.

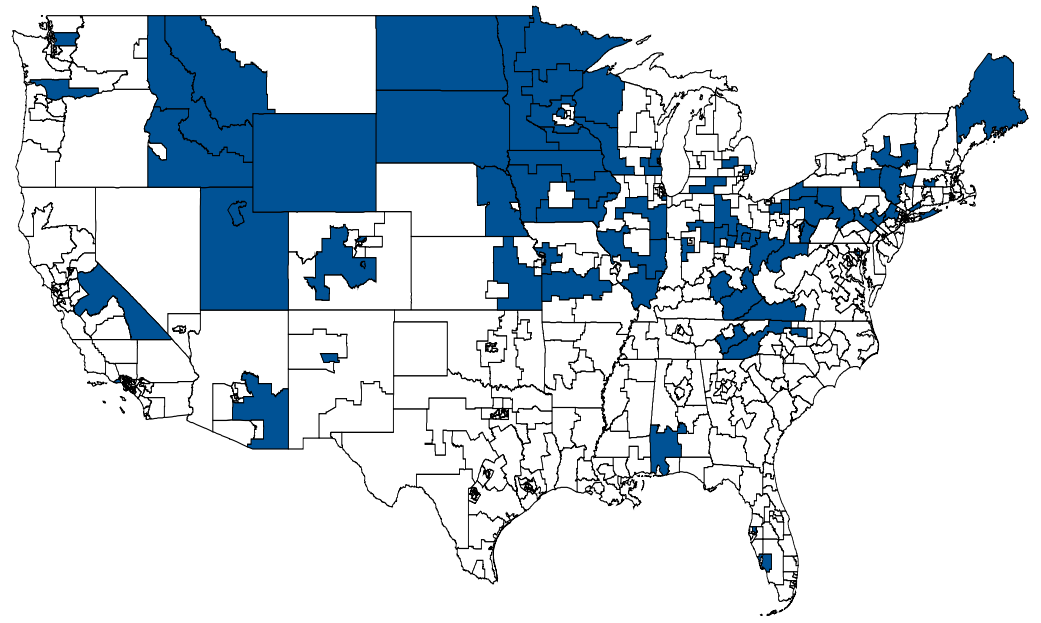

Figure 1.1 Sampled Geographic Areas

\footnotetext{
${ }^{1}$ Several additional reports will be issued as part of the national evaluation that address: indoor air quality in weatherized homes; energy savings and non-energy benefits attributable to weatherization activities; a process evaluation report; a series of case studies for WAP agencies; a program characterization and eligible population report; and an occupant/client satisfaction report. See http://weatherization.ornl.gov

${ }^{2}$ See Pigg et al. 2014.
} 
The next section of this report describes the data that were collected and how the data were processed for analysis. Section 3 presents the results, beginning with characteristics of the refrigerators in the study and continuing with assessments of inside temperatures and energy consumed. 


\section{DATA COLLECTION AND PREPARATION}

\subsection{DATA COLLECTION}

The bulk of the IAQ study was conducted during the winter of 2010-2011. Fieldwork for the IAQ study consisted of four site visits to each home. Visit 1 and visit 2 were before weatherization. During visit 1 the refrigerator temperature data were collected and the refrigerator power meter was installed. During visit 2, usually about 7 days later, the refrigerator power logger was retrieved. During visits 1 and 3, a detailed survey was conducted to record the general characteristics of the home and equipment including the characteristics of the primary refrigerator and secondary refrigerator, if present. In addition, all participants in the IAQ study were administered an extensive telephone survey, called the Occupant Survey $^{3}$, covering a number of topics including basic demographics, indoor comfort, and health issues.

A logger recorded refrigerator temperature while the technician was on site during site visit number 1 , typically less than two hours. Temperature data were collected on 159 refrigerators, all primary refrigerators. The temperature log files were combined into a single comma-separated value (CSV) file with 16,411 records. The one-minute records include site identifier, timestamp, and temperature in degrees Fahrenheit.

Refrigerator power data were collected for primary refrigerators and some secondary refrigerators during pre-weatherization and post-weatherization field visits. Refrigerator power loggers were installed during site visit 1 and retrieved during site visit 2 with duration of about one week. This process was repeated during visits 3 and 4 for selected refrigerators.

The logger files were combined into a single CSV file with almost five million records. The data fields are site identifier, refrigerator identifier, elapsed minutes, instantaneous watts, accumulated watt-hours, and a power cycle indicator (e.g., power outage). Table 2.1 shows the power data sample counts for the 405 sites with 459 refrigerators. This report will focus on the 382 primary refrigerators with data collected during the pre-weatherization visit. ${ }^{4}$

Table 2.1 Number of Refrigerators with Power Data

\begin{tabular}{|l|c|}
\hline \multicolumn{1}{|c|}{ Refrigerator Sample } & Frequency \\
\hline Primary refrigerator, pre-weatherization & 382 \\
\hline Secondary refrigerator, pre-weatherization & 15 \\
\hline Primary refrigerator, post-weatherization & 61 \\
\hline Secondary refrigerator, post-weatherization & 1 \\
\hline Total & 459 \\
\hline
\end{tabular}

\subsection{PREPARATION OF THE REFRIGERATOR TEMPERATURE DATA FOR ANALYSIS}

Figure 2.1 shows a plot of temperature for a refrigerator operating normally. The site visit is too short to capture a full day of operation which would include time-of-day variations of refrigerator use and defrost cycle. Unfortunately, many of the recordings were too short to capture the maximum temperature, the minimum temperature, or both.

\footnotetext{
${ }^{3}$ See Carroll et al. 2014 for a detailed description of the Occupant Survey

${ }^{4}$ The project team was unable to revisit a substantial number of refrigerators post-weatherization, which is why this report focuses on data collected pre-weatherization.
} 


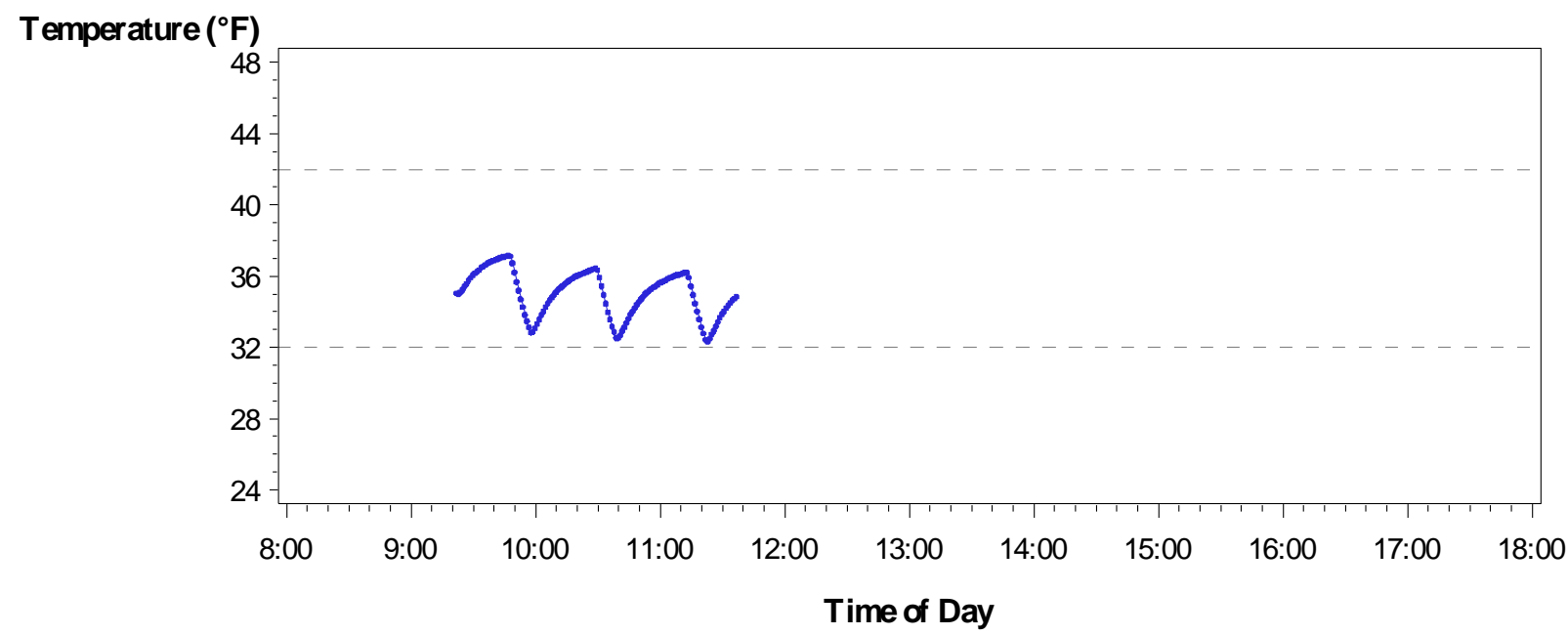

Figure 2.1 Typical Refrigerator Temperature

Data quality flags were created to identify the absence of recorded minimum temperature and maximum temperature and these filters were applied to statistical summaries of minimum temperature, maximum temperature, temperature range, and measures of healthy temperature. Table 2.2 shows that 112 (70 percent) of the temperature logs recorded both minimum temperature and maximum temperature.

Table 2.2 Number of Refrigerators with Minimum and Maximum Recorded

\begin{tabular}{|r|c|c|c|}
\hline \multirow{2}{*}{ Minimum Temperature Recorded } & \multicolumn{4}{|c|}{ Maximum Temperature Recorded } \\
\cline { 2 - 4 } & No & Yes & Total \\
\hline No & 24 & 23 & 47 \\
\hline Yes & 0 & 112 & 112 \\
\hline Total & 24 & 135 & 159 \\
\hline
\end{tabular}

For those units where both maximum and minimum temperatures were observed, the average metering time was 1.7 hours. For those with incomplete range measurements, the average was about 1.3 hours.

\subsection{PREPARATION OF THE REFRIGERATOR POWER DATA FOR ANALYSIS}

Logger failures occurred resulting in loss of data. The meter contains a calibration table that was, on occasion, corrupted. As a result, 27 refrigerator files were deleted and 21 were truncated by data quality filters applied during preparation of the data for analysis.

Annual $\mathrm{kWh}$ was computed for each refrigerator as the average 1-minute watt-hours times 60 times 24 times 365 divided by 1000 .

Figure 2.2 is a plot of instantaneous power for a selected refrigerator. Data points equal to 0 watts correspond to when the compressor is off and data points equal to approximately 100 watts correspond to when the compressor is one. The infrequent readings of approximately 380 watts correspond to when the defrost cycle is operating. Power levels consumed are low and the refrigerator compressor is often off while minimum temperature is maintained. However, there were tremendous variations among the sampled units in power levels and run times. 


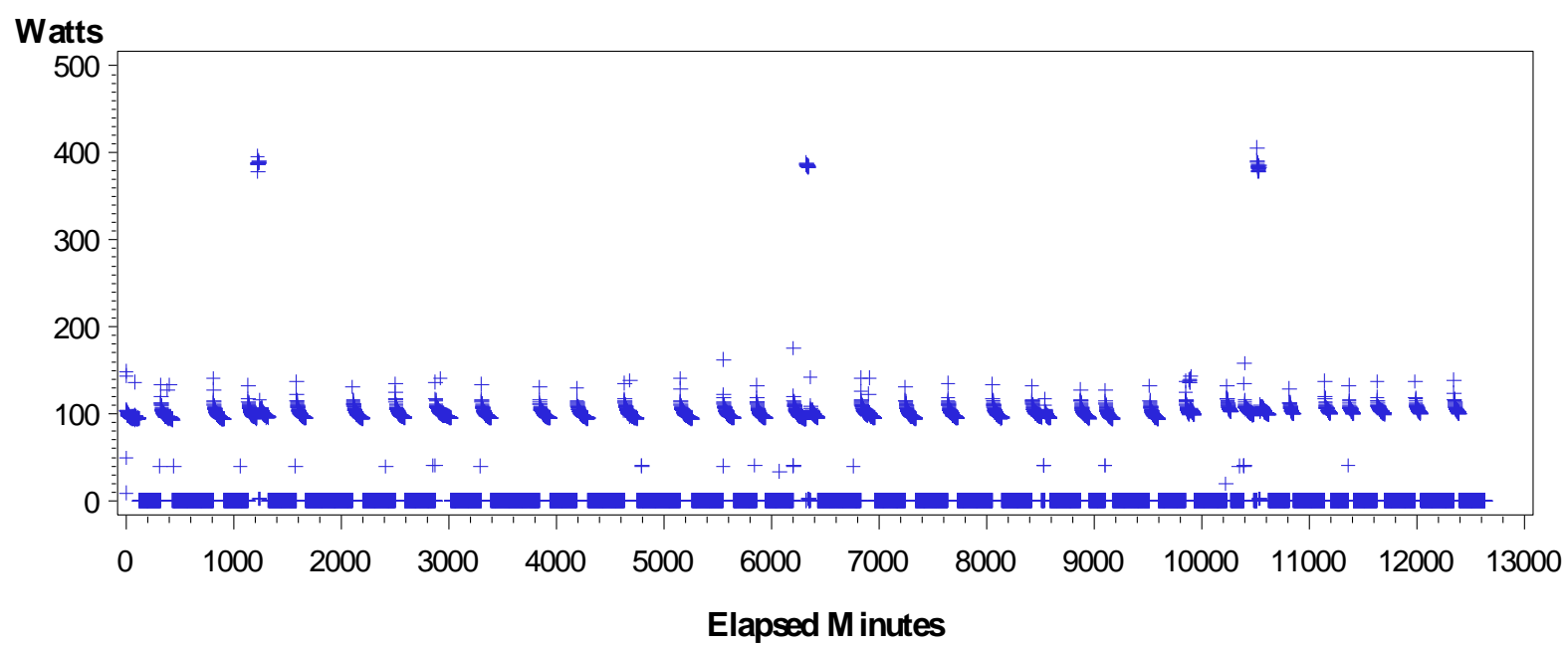

Figure 2.2 Example of Refrigerator Power (watts) Over Time (in minutes) 



\section{REFRIGERATOR CHARACTERIZATION AND PERFORMANCE}

Table 3.1 describes the characteristics of the 382 primary refrigerators found in the IAQ study of homes pre-weatherization. Most have top freezers (67\%) and almost all have automatic defrosters (96\%). This set of refrigerators has fewer additional features, such as through the door water dispensers $(26 \%)$ and anti-sweating technology (19\%). Only $23 \%$ of the refrigerators had an energy saver switch and of these, the switch was set to on in only $55 \%$ of the cases. Also impacting refrigerator energy use is the fact that $34 \%$ of the refrigerators are not located in conditioned spaces, which could lead to reduced or increased energy consumption (e.g., if outside in winter or summer). Many refrigerators are located in basements $(25 \%)$ and garages $(18 \%)$. Forty five $(9 \%)$ of the homes had a secondary refrigerator and 6 homes (1\%) had a third refrigerator.

Figure 3.1 plots the dates that the primary refrigerators were manufactured. Almost $40 \%$ were manufactured between 2007 and 2010. Just over 25\% were manufactured before the year 2000. One refrigerator was manufactured in the early 1970s. As indicated in Figure 3.2, most of the refrigerators have a capacity of about 18 cubic feet, though a fair number have higher capacities.

To protect family members from foodborne illness, the U.S. Department of Agriculture (USDA) recommends that the refrigerator temperature be $40{ }^{\circ} \mathrm{F}$ or below. ${ }^{5}$ Furthermore, the USDA recommends that food stored at temperatures above $40^{\circ} \mathrm{F}$ for more than 2 hours should not be consumed due to a risk of food poisoning. ${ }^{6}$ Table 3.2 presents results from monitoring the temperature inside the primary refrigerators during the first IAQ study visit. On average, the refrigerators in the sample meet this requirement. However, upon closer inspection, of the 112 refrigerator meter files with both minimum and maximum temperature recorded, $25(22 \%)$ had temperatures above $41^{\circ} \mathrm{F}$. Table 3.3 summarizes the characteristics of these two groups. Note that the temperature range is much wider for the refrigerators where the temperature rises above $41^{\circ} \mathrm{F}$.

A healthy refrigerator score was defined as the percentage of time that the metered temperature was below $42{ }^{\circ} \mathrm{F}$. Figure 3.3 plots the distribution of refrigerators by this measure. Over $80 \%$ of the refrigerators scored a perfect $100 \%$. It is surprising to see three refrigerators with a healthy score of zero. Figure 3.4 shows an example where the temperature meter captured four cooling cycles all above $41^{\circ} \mathrm{F}$.

\footnotetext{
${ }^{5}$ http://www.fsis.usda.gov/wps/portal/fsis/topics/food-safety-education/get-answers/food-safety-fact-sheets/safe-foodhandling/refrigeration-and-food-safety/ct_index/!ut/p/a1/jZFRT8IwEMc_DY_d3RwS8G1ZYmDKkBCl7IWUreuabO3SVqdest8EQNK7613v3979z_IgUKu2JsUzEmtWHO855M9rnESzhJMV7PwHhfZy3r1kCQ43dx6YPcHkEVX6icGP_Tp1d8cGOWyVJA3jFXE6kqDVRwR5iyPTcWaKV1SSyruPsgFSscsTXnzheOOTJUa6bKRioB1PDKSMHN4JB_oyQ_5E ALt5eq5Owhfy0NQx9LLJoM56nWYSr8W gjHffwGVz PSi0YdhUbtYHaKpH9N3yA03wavx6dq5zt6NcIR93wdCa9HwoNDtCM9Jam0d OFMSuvaZfj7Gc5RP7XZq4y8BE-W7/\#4

${ }^{6}$ National Occupant Survey (see Carroll et al. 2014 for a detailed description of this survey): 1.1\% of treatment group respondents reported a household member suffered from food poisoning pre-weatherization during the previous year. This dropped to $0.3 \%$ post-weatherization. The results for a comparison group one year and two years post-weatherization are $0.2 \%$ and $0.2 \%$, respectively. From the survey of IAQ households pre-weatherization, $0.6 \%$ of households reported a member suffered from food poisoning during the previous year.
} 
Table 3.1 Primary Refrigerator Characteristics

\begin{tabular}{|c|c|}
\hline $\begin{array}{r}\text { Bottom freezer } \\
\text { Side-by-side } \\
\text { Top freezer } \\
\text { Other }\end{array}$ & $\begin{array}{r}4 \% \\
29 \% \\
67 \% \\
0 \%\end{array}$ \\
\hline Type of defroster & $\begin{array}{r}96 \% \\
4 \%\end{array}$ \\
\hline Ice maker present & $\begin{array}{l}56 \% \\
44 \%\end{array}$ \\
\hline Through the door water dispenser present & $\begin{array}{l}74 \% \\
26 \%\end{array}$ \\
\hline Anti-sweat feature present & $\begin{array}{l}81 \% \\
19 \%\end{array}$ \\
\hline Anti-sweat s & $\begin{array}{l}52 \% \\
48 \%\end{array}$ \\
\hline Energy-saver switch present & $\begin{array}{l}77 \% \\
23 \% \\
\end{array}$ \\
\hline Energy-saver setting* & $\begin{array}{l}45 \% \\
55 \%\end{array}$ \\
\hline $\begin{array}{r}\text { Kitchen } \\
\text { Basement } \\
\text { Garage } \\
\text { Other living space } \\
\text { Hall } \\
\text { Porch } \\
\text { Other living space }\end{array}$ & $\begin{array}{r}27 \% \\
25 \% \\
18 \% \\
14 \% \\
5 \% \\
5 \% \\
5 \% \\
\end{array}$ \\
\hline Refrigerator is in conditioned space & $\begin{array}{l}34 \% \\
66 \%\end{array}$ \\
\hline Refrigerator is plugged in & $\begin{array}{l}12 \% \\
88 \%\end{array}$ \\
\hline Have a secondary refrigerator & $\begin{array}{r}91 \% \\
9 \%\end{array}$ \\
\hline Have a third refrigerator & $\begin{array}{r}99 \% \\
1 \% \\
\end{array}$ \\
\hline
\end{tabular}

* For refrigerators with this setting 


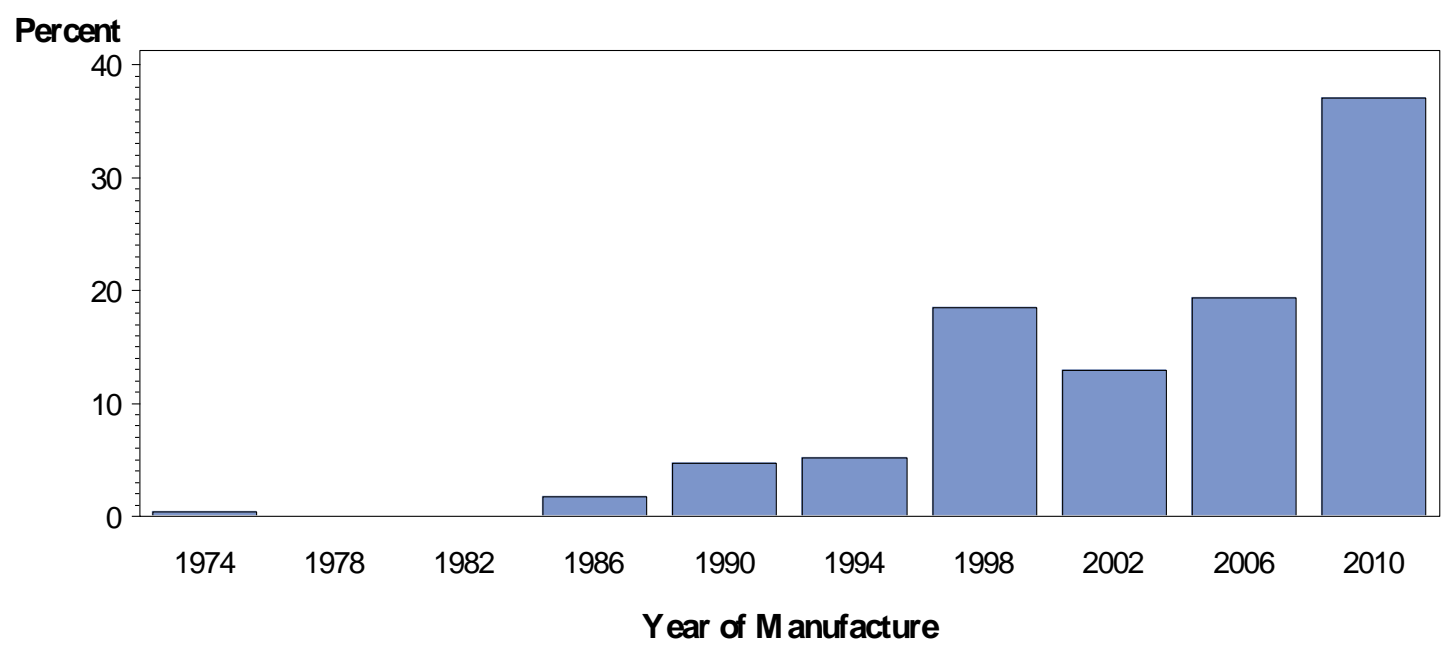

Figure 3.1 Year Primary Refrigerator Was Manufactured (in \%)

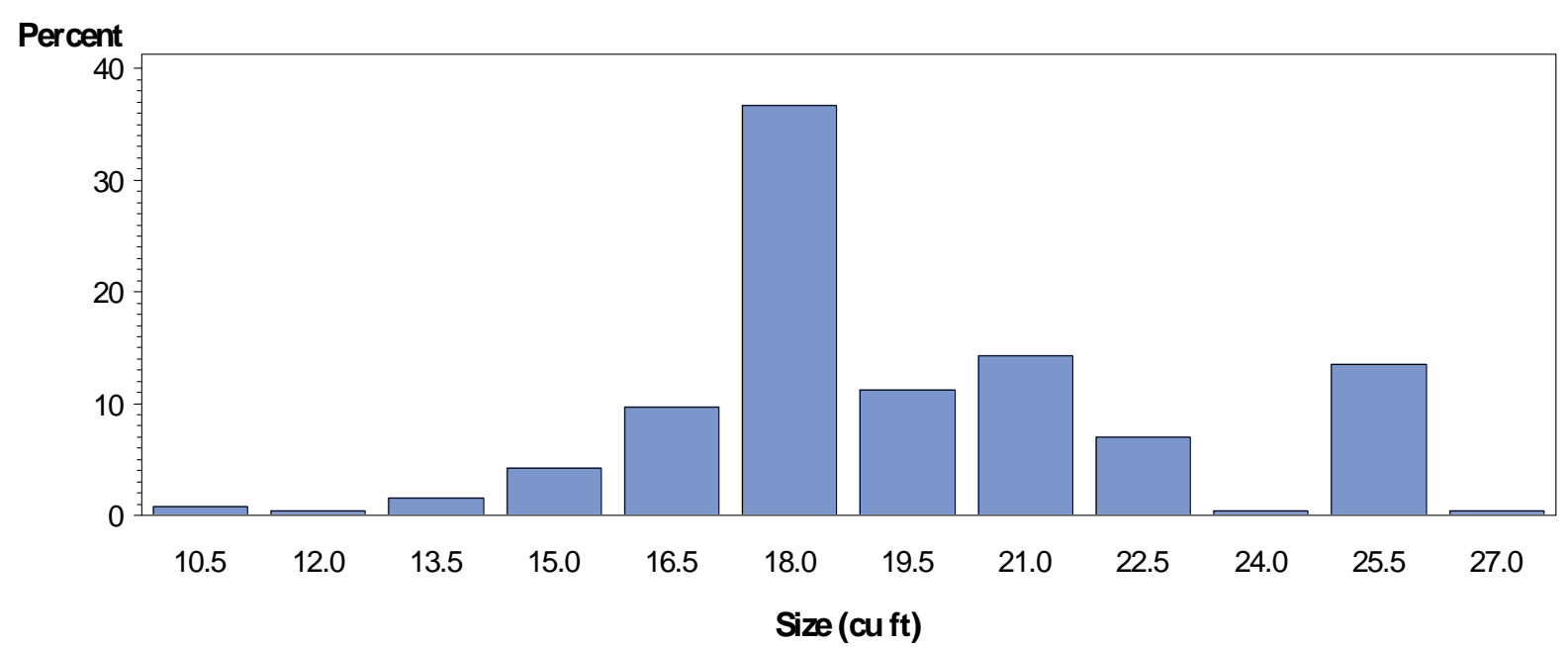

Figure 3.2 Primary Refrigerator Size (in \%)

Table 3.2 Average Refrigerator Temperature Measurements

\begin{tabular}{|r|r|}
\hline Average measurement of... & \\
Average temperature & $37.7^{\circ} \mathrm{F}$ \\
Minimum temperature & $36.2^{\circ} \mathrm{F}$ \\
Maximum temperature & $39.4^{\circ} \mathrm{F}$ \\
Temperature range & $3.1^{\circ} \mathrm{F}$ \\
Metering time & 1.6 hours \\
\hline
\end{tabular}


Table 3.3 Characteristics of Refrigerators That Do and Do Not Maintain Temperature Less than $42{ }^{\circ} \mathrm{F}$

\begin{tabular}{|r|r|r|}
\hline \multirow{2}{*}{} & \multicolumn{2}{|c|}{$\begin{array}{c}\text { Temperature was observed } \\
\text { to be above 42 }{ }^{\circ} \mathbf{F}\end{array}$} \\
\cline { 2 - 3 } No & \multicolumn{1}{|c|}{ Yes } \\
\hline Average measurement of... & & \\
Average temperature & $36.6{ }^{\circ} \mathrm{F}$ & $41.6^{\circ} \mathrm{F}$ \\
Minimum temperature & $35.2^{\circ} \mathrm{F}$ & $39.6{ }^{\circ} \mathrm{F}$ \\
Maximum temperature & $37.9^{\circ} \mathrm{F}$ & $43.8^{\circ} \mathrm{F}$ \\
Temperature range & $2.7^{\circ} \mathrm{F}$ & $4.2^{\circ} \mathrm{F}$ \\
Metering time & 1.8 hours & 1.8 hours \\
\hline
\end{tabular}

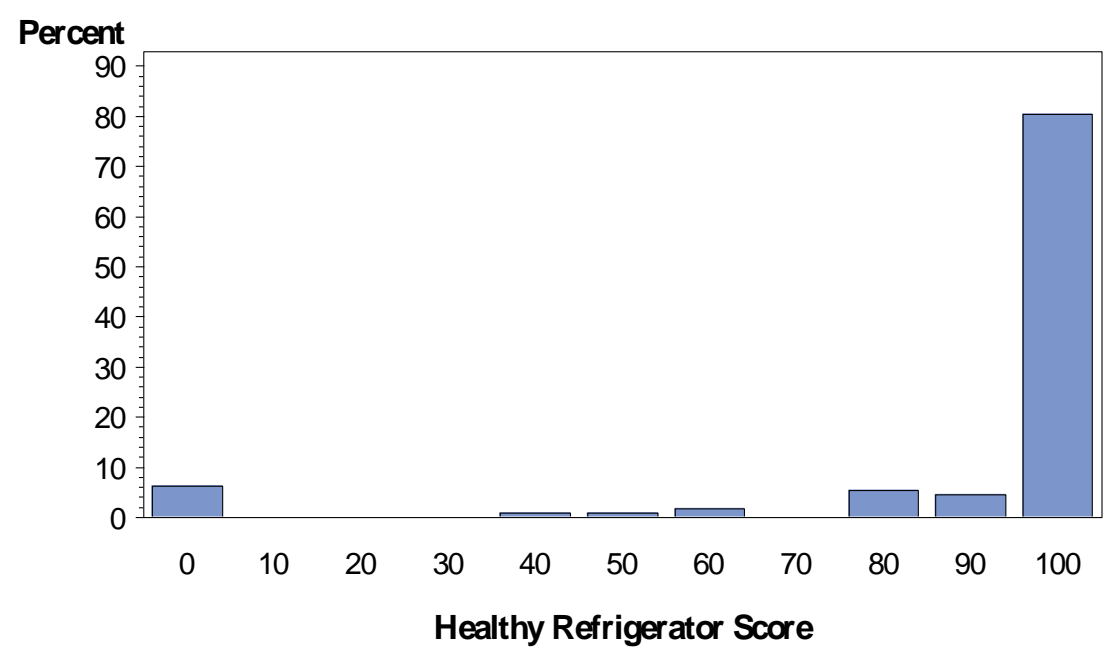

Figure 3.3 Distribution of the Healthy Refrigerator Score (in \%)

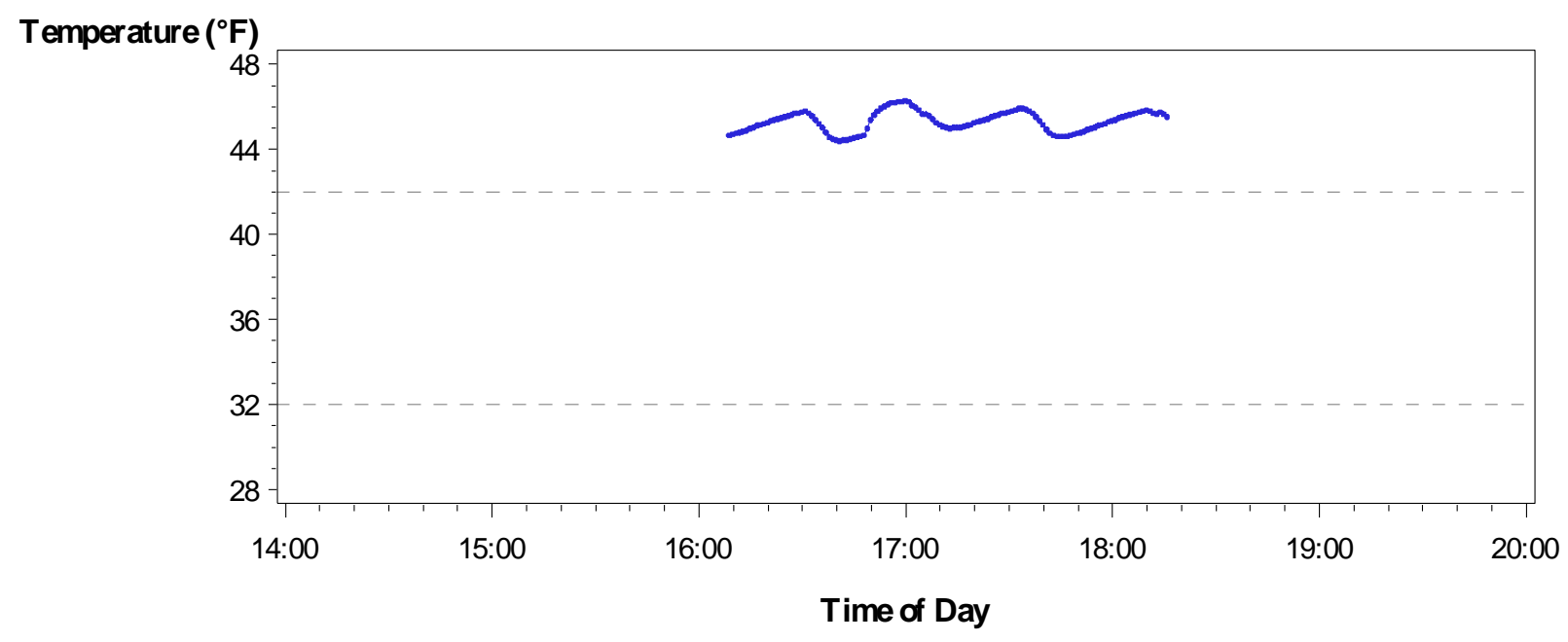

Figure 3.4 Example Where the Refrigerator Temperature was Always Above $42{ }^{\circ} \mathrm{F}$ 
The average annualized electricity consumption for the set of primary refrigerators is $756 \mathrm{kWh} / \mathrm{year}$. The median is $651 \mathrm{kWh} /$ year. Figure 3.5 illustrates the skewed distribution of consumption, by the percentage of refrigerators in the sample. The variation in consumption has many possible explanations, including: different nameplate ratings, refrigerator capacity, age, indoor temperatures, location in unconditioned spaces, number of individuals in the household (i.e., influencing the number of door openings), number of operating options, and simple disrepair. It should be noted that the average electricity consumption of this set of refrigerators is possibly an underestimate given that the data were collected during the winter, the preponderance of the study houses are located in cold to very cold climates, and a large percentage of the refrigerators are located in unconditioned spaces.

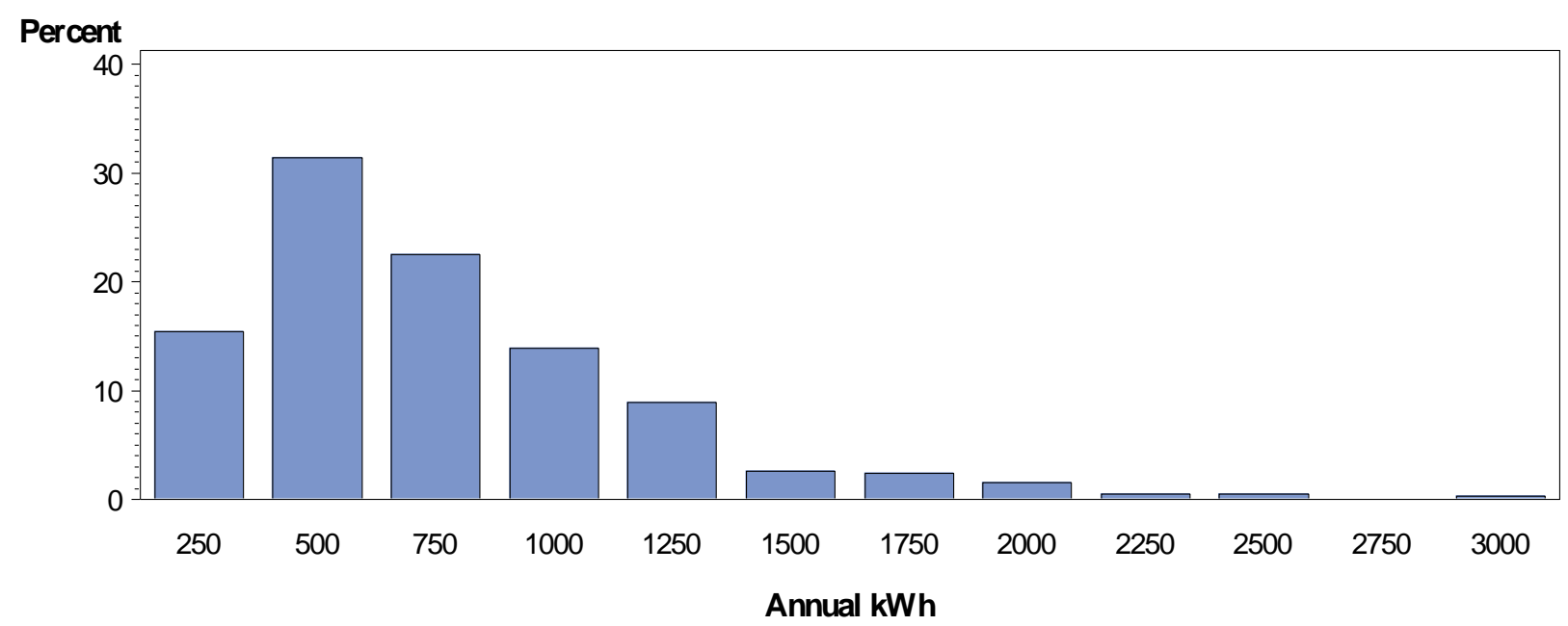

Figure 3.5 Annual Refrigerator Electricity Consumption (kWh/year)

A regression model was estimated to try to more formally explain the variation in annual power consumption across the set of primary refrigerators in the database. Table 3.4 presents the results. The most significant variable is refrigerator age. Not surprisingly, this result supports the more general observation that refrigerator efficiency has been improving markedly over time (See Figure 3.6). Conversely, and also not unexpected, energy use increases as the capacity of the refrigerator increases. Side-by-Side refrigerator-freezers consume more energy when compared to the other most common types, namely top-freezer refrigerators. An extra feature such as an ice maker does result in an increase in energy use, though this variable is insignificant. These four independent variables result in a model with a high adjusted $\mathrm{R}^{2}(0.427)$ that is highly statistically significant. Variables that were tested in this model but were dropped due to being highly insignificant included: primary refrigerator located in a conditioned space; indoor temperature thermostat setting in the summer; indoor temperature thermostat setting in the winter; the presence of an energy saver switch; and the number of individuals in the household. It was somewhat unexpected that all of these variables would prove to be highly insignificant. 


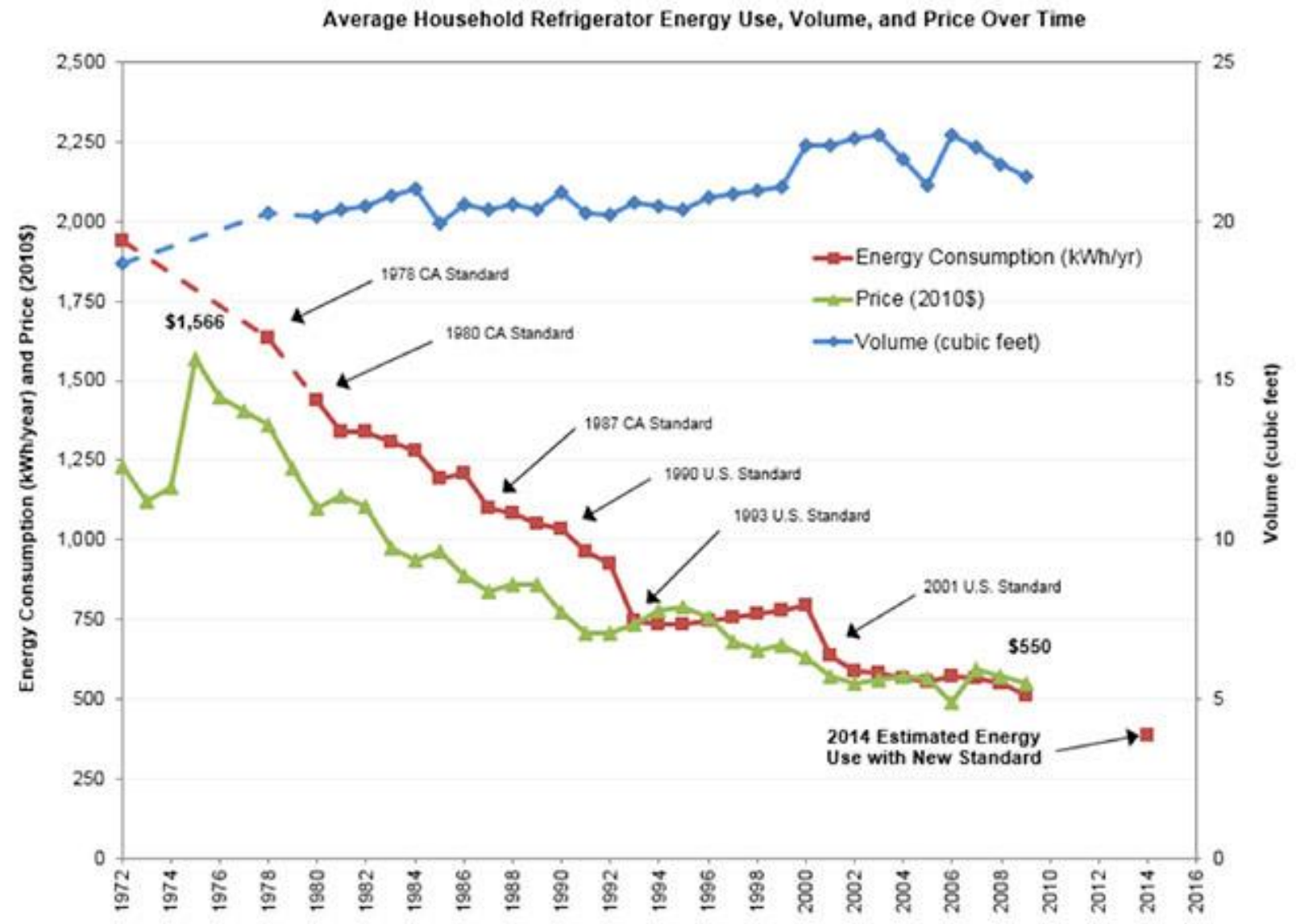

Figure 3.6 Average Household Refrigerator Energy Use, Volume, and Price Over Time ${ }^{7}$

Table 3.4 Refrigerator Regression Model: Dependent Variable Annual Energy Consumption

\begin{tabular}{|c|c|c|c|c|c|}
\hline \multirow[b]{2}{*}{ Model } & \multicolumn{2}{|c|}{ Unstandardized Coefficients } & \multirow{2}{*}{$\begin{array}{c}\text { Standardized } \\
\text { Coefficients } \\
\text { Beta } \\
\end{array}$} & \multirow[b]{2}{*}{$\mathrm{t}$} & \multirow[b]{2}{*}{ Sig. } \\
\hline & B & Std. Error & & & \\
\hline (Constant) & -89.558 & 222.594 & & -.402 & .688 \\
\hline Has Ice Maker & 72.803 & 66.448 & .110 & 1.096 & .276 \\
\hline Refrigerator Age & 23.436 & 3.894 & .473 & 6.019 & .000 \\
\hline Fridge Side by Side & 188.692 & 82.723 & .254 & 2.281 & .025 \\
\hline Refrigerator size $\left(\mathrm{ft}^{3}\right)$ & 23.201 & 11.923 & .220 & 1.946 & .055 \\
\hline $\begin{array}{l}\mathrm{R} 2=.452 ; \mathrm{ADJ} . \mathrm{R} 2=.427, \\
\text { Sign. }=.000\end{array}$ & & & & & \\
\hline
\end{tabular}

${ }^{7}$ (Source: http://aceee.org/blog/2014/09/how-your-refrigerator-has-kept-its-co ) 
The relationship between annualized energy use and healthiness was explored. This relationship was explored in two ways. First, the correlation between the annual energy use and the before-defined healthy refrigerator score was estimated. The Pearson Correlation (2-tailed) is 0.17 with a significance of 0.12 , which is generally not considered to be statistically significant. Second, the energy consumption and healthy refrigerator scores were plotted, as shown in Figure 3.7. This figure indicates that refrigerators with largely unhealthy interior temperatures have relatively low energy consumption. In other words, instead of operating inefficiently by having longer on-cycles to try to get the temperatures down in the interior, these refrigerators actually use less energy. Potential explanations include mis-calibrated thermostats and problems causing compressors to short cycle. An indication that this phenomenon is appreciated by local weatherization crews is that the average healthy refrigerator score and annual energy consumption are low, 67 and $633, \mathrm{kWh}$, respectively, for primary refrigerators that were replaced for health reasons (i.e., non-energy conservation measures).

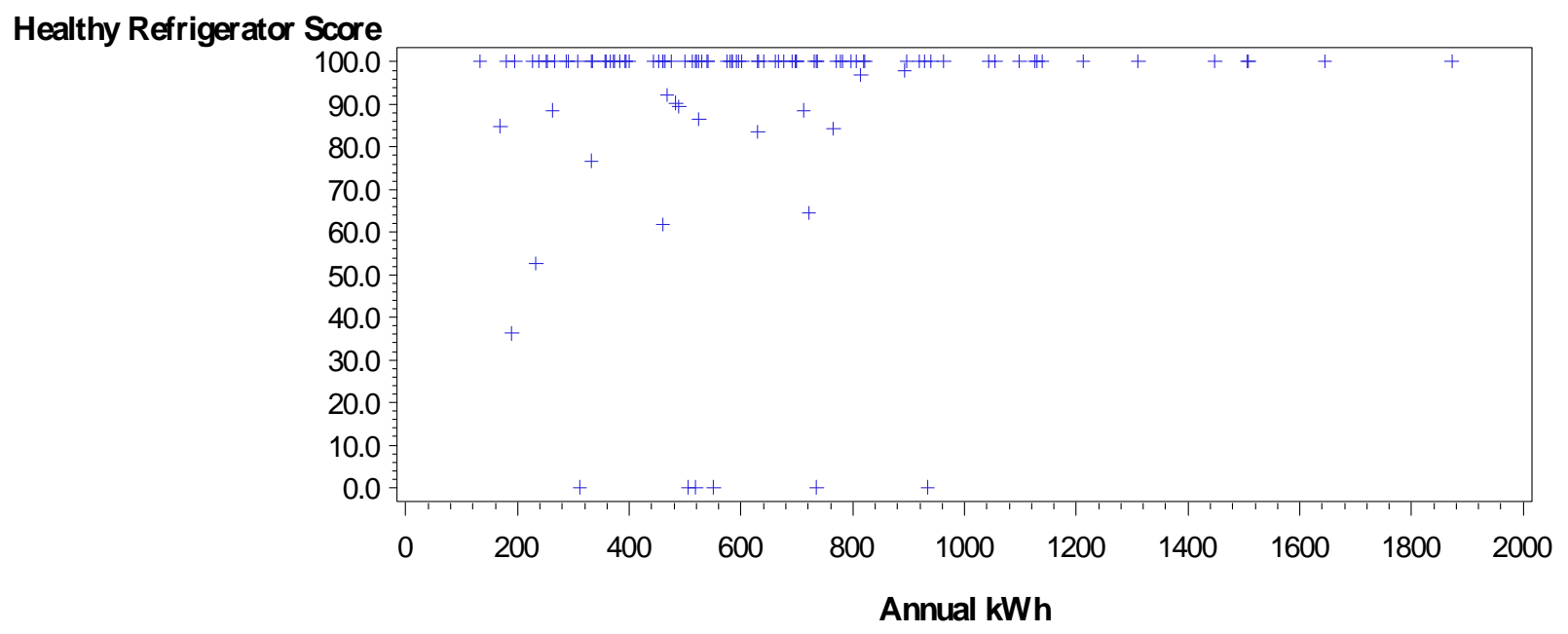

Figure 3.7 Annualized Refrigerator Energy Consumption by Healthy Refrigerator Score 
The households that participated in the national IAQ study were administered an extensive occupant survey. The survey contained questions on household energy use behavior, demographics, and health. One health-related question that is pertinent to this study asked whether anyone in the household had suffered food poisoning in the previous year. Three households indicated that one or more household members had suffered from food poisoning. The annualized energy consumption for these three primary refrigerators was $311 \mathrm{kWh}, 543 \mathrm{kWh}$, and $477 \mathrm{kWh}$, respectively, well below the national average energy consumption of $756 \mathrm{kWh}$. Unfortunately, data on the temperature inside these refrigerators was not collected. Also, it cannot be discerned from the survey the cause of the food poisoning (i.e., caused by food not sufficiently refrigerated). Thus, these results are illustrative of the types of data that could be collected by future research. 



\section{CONCLUSIONS}

This report assesses the characteristics and performance of a set of refrigerators found in WAP eligible homes that participated in a national study of the impacts of weatherization on indoor environmental quality. The study primarily focuses on a set of 382 primary refrigerators and data collected about their operation pre-weatherization. The typical refrigerator found in the study homes was manufactured after the year 2000, has a capacity of 18 cubic feet, and has a top freezer. Only $27 \%$ of the primary refrigerators are located in kitchens and $34 \%$ are not located in conditioned spaces. Only $23 \%$ of the refrigerators had an energy-saver switch and of these, only $48 \%$ of the switches were observed to be in the on position, but the energy-saver feature was not found to correlate with lower energy use anyway. The preponderance of the refrigerators' inside temperatures was below the recommended $40^{\circ} \mathrm{F}$. The average annualized electricity consumption for a refrigerator in the sample was $756 \mathrm{kWh} / \mathrm{year}$. The median was $651 \mathrm{kWh} /$ year.

Most of the results were expected. For example, it was expected that most refrigerators found in this set of WAP eligible homes would be modest in size. It was certainly expected that the age and capacity of refrigerators would impact their annual energy use. It was somewhat unexpected that variables that describe refrigerators' surroundings (i.e., being in an unconditioned space, indoor temperature settings) were not significantly related to annual energy use. It was expected that refrigerators that exhibited unhealthy interior temperatures used relatively less energy. Lastly, it was unexpected that so many energy saver switches were found to be in the off position. This finding could be a point of emphasis in client energy education practiced by the Subgrantees.

There were a number of limitations to this study. The study was not able to monitor and meter new refrigerators installed by the weatherization program. Thus, this study was not able to estimate energy savings attributable to refrigerator replacement or the additional non-energy emission reduction benefits from refrigerator replacement. This study was not able to determine why energy-saver switches were seemingly ineffective. This study was not able to link unhealthy refrigerators to household health issues such as food poisoning due to the limitations of the occupant survey and the relatively small sample size relative to the reported frequency of this health issue. Future research could attempt to not only estimate the reduction in number of food poisoning events related to refrigerator replacement but also to monetize this benefit, as has been done for a number of other health-related benefits attributable to WAP such as reductions in asthma symptoms and thermal stress on occupants from exposure to extreme indoor temperatures (Tonn et al. 2014). 



\section{REFERENCES}

Carroll, D., Berger, J., Miller, C., and Driscoll, C. 2014. National Weatherization Assistance Program Impact Evaluation - Baseline Occupant Survey: Assessment of Client Status and Needs. ORNL/TM2015/22, Oak Ridge National Laboratory, Oak Ridge, Tennessee, October.

Pigg, S., Cautley, D., Francisco, P. with Hawkins, B., and Brennan, T. 2014. Weatherization and Indoor Environment Quality: Measured Impacts in Single-Family Homes Under the Weatherization Assistance Program. ORNL/TM-2014/170, Oak Ridge National Laboratory, Oak Ridge, Tennessee, September.

Tonn, B., Rose, E., Hawkins, B., and Conlon, B. 2014b. Health and Household-Related Benefits Attributable to the Weatherization Assistance Program. ORNL/TM-2014/345, Oak Ridge National Laboratory, Oak Ridge, Tennessee, September. 